Al-Bayyinah: Journal of Islamic Law-ISSN: 1979-7486 (p); $\underline{2580-5088}$ (e) Volume VI Number 2, pp. 17-28

\title{
PARADIGMA PERUBAHAN HUKUM ISLAM (Eksplorasi Pemikiran Ibnu Qayyim al-Jauziyah)
}

\section{Hj. St. Rahmawati}

(Dosen Tetap STAIN Watampone, Sulawesi Selatan, Indonesia, email: rahmawati.iainbone@gmail.com)

\section{Abstract}

Ibn Qayyim al-Jauziyah was commonly considered as a liberal Muslim thinker. In his thought about legal changes, he proposes five agents of changes, i.e. time, space, situation, intention, and custom. The legal changes, therefore, occur due to the changes of the five factors. Benefits can only by responding to the changes.

\section{Kata Kunci: Perubahan, Hukum, Ibnu Qayyim al-Jauziyah}

\section{PENDAHULUAN}

Hukum Islam merupakan sistem hukum yang diyakini mempunyai kebenaran universal. Universalitas hukum Islam tampak pada daya adaptatifnya yang melampaui batas-batas wilayah dan zaman. Oleh karena itu, hukum Islam senantiasa aktual seiring perkembangan peradaban manusia dan perubahan zaman. Dengan demikian, hukum Islam mesti diyakini sebagai tata nilai dan tata aturan yang diproyeksikan untuk menjadi solusi atas problematika hidup manusia dengan segala persoalan yang melingkupinya.

Secara dogmatis-teologis, hukum Islam yang bersumber dari wahyu Allah semata-mata diperuntukkan bagi manusia agar dapat menjalani kehidupannya secara beradab. Dalam artian bahwa Allah sama sekali tidak mempunyai kepentingan sedikit pun terhadap hukum Islam. Aturan-aturan atau ketentuan-ketentuan hukum Islam ditetapkan oleh Allah demi kemaslahatan hidup manusia. Dengan demikian, beban hukum (baca: taklif) hanya terdapat dan berlaku bagi manusia 
(mukallaf). Oleh karena itu, kewajiban, perintah, larangan, ketentuan halal serta haram dan sebagainya hanya berlaku bagi manusia. ${ }^{1}$

Kaitannya dengan tuntutan perubahan sosial dewasa ini, hukum Islam harus mampu memberikan jawaban yang memuaskan bagi kebutuhan manusia. Artinya, hukum Islam harus terlibat secara langsung dalam memecahkan persoalan manusia dalam kancah percaturan global. Oleh karena itu, konsepsi hukum Islam harus lebih dekat kepada manusia dan bukan sebaliknya, justru hukum Islam terkesan melangit, sehingga tidak menyentuh persoalan manusia dalam memenuhi kebutuhan hidupnya yang semakin kompleks. Hukum Islam memang merupakan ajaran agama langit (samawi), akan tetapi tidak berarti bahwa hukum Islam harus melangit, melainkan hukum Islam harus membumi.

Kehidupan manusia senantiasa mengalami perubahan adalah realitas yang tak terpungkiri, bahkan dipandang sebagai sunnatullah. Oleh karena itu, hukum Islam harus selalu diinterpretasi agar tetap menemukan konteksnya dalam kehidupan manusia yang senantiasa dinamis. Ketakutan dan ketidakmampuan menginterpretasi hukum Islam sesuai dengan perubahan zaman, dipandang sebagai ancaman yang maha dahsyat bagi kelangsungan dan eksistensi hukum Islam di tengah arus perubahan dewasa ini. Bahkan, dapat dikatakan bahwa ketidakberanian melakukan perubahan hukum merupakan pembunuhan karakter hukum Islam yang fleksibel dan dinamis. ${ }^{2}$

Terdapat banyak argumen teologis-filosofis yang mendasari perlunya melakukan perubahan hukum Islam, diantaranya:

1. Hukum Islam menganut teori "perubahan" demi terciptanya perbaikan dan kemajuan manusia dalam mewujudkan kemaslahatan. Doktrin perubahan dalam Islam tampak dalam pesan al-Qur'an yang mengatakan bahwa

${ }^{1}$ Lihat, Rahmatunnair, Responsibilitas Hukum Islam di Tengah Perubahan Sosial, Makalah, disampaikan pada kajian Rutin FKI Ulul Albab STAIN watampone tanggal 16 Mei 2009.

${ }^{2}$ Ibid. 
"sesungguhnya Allah tidak akan merubah nasib suatu kaum sebelum kaum itu sendiri merubah dirinya".

2. Epistemologi pemikiran hukum Islam tidak mempertentangkan antara ketentuan normatif dalam teks suci dengan realitas sosial masyarakat. Dalam hukum Islam, terdapat dialektika antara teks hukum dengan realitas sosial yang diformulasi dalam istilah Ijtihad. Idealitas hukum Islam dan realitas sosial adalah dua variabel yang tak terpisahkan dalam konsep ijtihad. ${ }^{3}$

Dalam konteks tersebut, perubahan hukum Islam berdasarkan pertimbangan perubahan sosial adalah sesuatu yang niscaya, bahkan keharusan. Dikatakan demikian karena merealisasi idealitas hukum Islam tidak boleh dilepaskan dari realitas sosial kehidupan manusia yang menjadi objek dari idealitas hukum. Dengan demikian, kenyataan kehidupan sosial manusia harus diajak berdialog untuk memproyeksikan sebuah perubahan formulasi hukum Islam. Pada gilirannya, terbangun suatu formulasi pemikiran hukum Islam yang diterima oleh realitas kemanusiaan yang sangat produktif menciptakan perubahan-perubahan yang signifikan.

Kendatipun demikian, terdapat perbedaan pandangan antara ulama fikih dan ulama ushul dalam memahami hukum, pada gilirannya melahirkan perbedaan teori perubahan hukum. Dalam implementasinya, hukum yang telah ditetapkan ulama fikih bisa berubah dengan merujuk pada hukum yang ditetapkan ulama ushul. Mengacu dari sini, Ibnu Qayyim al-Jauziyah merumuskan teori tentang hukum dan selanjutnya akan dieksplorasi lebih jauh dalam tulisan ini.

\section{PEMBAHASAN}

\section{A. Biografi Singkat Ibnu Qayyim}

Ibnu Qayyim bernama lengkap Abu Abdullah Syamsuddin Muhammad bin Abu Bakar bin Ayyub bin Saad alDamasyqy al-Jauziyah dan dikenal dengan nama Ibnu Qayyim al-Jauziyah. Beliau dilahirkan pada tahun $691 \mathrm{H}$ bertepatan 1292 $\mathrm{M}$ dan wafat di tahun $751 \mathrm{H}$ bertepatan dengan tahun 1350

${ }^{3}$ Lihat, Rahmatunnair, Dialektika Hukum Islam, Makalah, disampaikan pada Pelatihan Epistemologi PMII Cabang Bone pada tanggal 7 Maret 2009 di Kampus STAIN Watampone. 
M. ${ }^{4}$ Ibnu Qayyim al-Jauziyah termasuk pemikir dan ahli fikih yang bermazhab Hanbali.

Ibnu Qayyim belajar kepada Ali Shihab al- Nablisi alQabir dan kepada ulama-ulama lainnya. Gurunya yang paling berpengaruh baginya adalah Ibnu Tyimiyah. Kendatipun demikian, beliau tidak jarang berbeda pendapat dengan gurunya apabila menurutnya sesuatu itu benar dan jelas dalilnya. Ilmu yang diperolehnya diajarkan pula kepada murid-muridnya seperti Ibnu Katsir, al-Hafidz Zainuddin Abu al-Fariz Abdurrahman, Syamsuddin Muhammad bin Abd Qahhar alNablisi, Ibn al-Hadi dan lain-lainnya. Di samping itu, beliau juga dikenal sebagai orang wara', rajin beribadah dan berpendirian teguh. Ibadah haji ke Mekkah sering dilakukannya, bahkan penduduk Mekkah kagum melihatnya beribadah dan melakukan tawaf. ${ }^{5}$

Bersama gurunya Ibnu Taymiyah, Ibnu Qayyim dimasukkan ke penjara karena mengharamkan berhaji ke mesjid Ibrahim. Di samping menguasai ilmu fikih, beliau menguasai berbagai cabang ilmu pengetahuan seperti filsafat, hadis, tarikh, serta kalam. Beliau terkenal berpegang teguh dalam membela kemurnian al-Qur'an dan hadis. Di samping itu, Ibnu Qayyim juga menentang keras berbagai paham sufi yang menurutnya bertentangan dengan al-Qur'an dan hadis, seperti; wahdatul wujud, ittihad maupun hulul. Paham-paham tersebut menurutnya lebih banyak menggunakan konsepsi akal, karena tidak jelas rujukan sumbernya. ${ }^{\circ}$ Pendapatnya dipandang cukup tegas karena tidak saja bersifat kritis terhadap berbagai aliran, akan tetapi kerapkali terjadi perbedaan pendapat dengan ulama fikih mazhab Hanbali.

Ibnu Qayyim sebagai sosok pemikir dan pembaharu, berusaha mengajak kembali berpegang teguh kepada al-Qur'an dan al-sunnah sebagaimana yang dilakukan oleh para ulama

\footnotetext{
${ }^{4}$ Mengenai tahun wafatnya terdapat perbedaan. Dalam kitab Dar alMa'arif al-Islamiyah disebutkan bahwa beliau meninggal tahun $1356 \mathrm{M}$. Sementara dalam kitab I'lam al-Muwaqi'in disebutkan tahun meninggalnya pada $1350 \mathrm{M}$.

${ }^{5}$ Lihat Abdul Mu'im al-Hifny, Mausu'at al-Sufiyah (Cet. I; Kairo: Dar ar-Rasyad, 1992), h. 333.

${ }^{6}$ Lihat Abdillah F. Hasan, Tokoh-tokoh Mashur Dunia Islam (Cet. I; Surabaya: Jawara, 2004), h. 227.
} 
salaf. Beliau juga mengajak untuk meninggalkan perbedaan dan pertikaian aliran. Di samping itu, ia mengajak pula kepada kebebasan berfikir dan memahami jiwa syari'ah dan menjauhi taklid, tidak hanya di bidang fikhi tetapi juga di bidang ilmu kalam dan tasawwuf. Dalam periode tasyri', Ibnu Qayyim termasuk dalam periode keenam. Periode ini ditandai dengan meluasnya paham fanatik dan taklid kepada imam yang empat. Beliau menolaknya dengan membuka pintu ijtihad dan kebebasan berpikir. $^{7}$

Ibnu Qayyim termasuk penulis produktif, dan karyakaryanya banyak diminati kalangan muslimin. Hingga kini ditemukan beberapa hasil karyanya mengenai tauhid, seperti Syifa al-Alil fi masail al-Qadha wa al-Qadar, Ar-Ruh, dll. Dalam masalah fikhi dan ushul fikhi, seperti I'lam alMuwaqqi'in, Bayan ad-dalil ala Istiqna al-Musabaqat 'an atTahlil, dll. Dalam ilmu tasawwuf, seperti Iddat as-Sabirin, AlFawaid, dll. Dalam ilmu sejarah, seperti Akhbar an-Nisa, Zaad al-Ma'ad, dll.

\section{B. Pemikiran Ibnu Qayyim al-Jauziyah Tentang Perubahan Hukum}

Menurut Ibnu Qayyim al-Jauziyah bahwa perubahan hukum terjadi karena perubahan fatwa. Sedangkan perubahan fatwa terjadi perubahan aspek-aspek yang mengitari hukum iu. Dalam kitabnya I'lam al-Muwaqqi' in, al-Jauziyah mengatakan:

$$
\begin{aligned}
& \text { فى تغير الفتوى, و اختلا فها بحسب الان زمنة و الا مكنة و الا } \\
& \text { حو ال و النيا ت و العوى ائد } 8
\end{aligned}
$$

Artinya:

Perubahan fatwa dan adanya perbedaan hukum tentang disebabkan faktor zaman, faktor tempat, faktor situasi, faktor niat, dan faktor adat.

Landasan teori pandangan al-Jauziyah tentang perubahan hukum, pada prinsipnya mengacu hakikat syari'at Islam yang senantiasa berorientasi kemaslahatan manusia.

${ }^{7}$ Lihat Departemen Agama RI, Ensikopedi Islam di Indonesia (Jakarta: Direktorat Jenderal Pembinaan kelembagaan Agama Islam Depag RI, 1992), h. 403-405.

${ }^{8}$ Ibnu Qayyim al-Jauziyah, I'lam al-Muwaqqi'in 'an Rab al-'Alamin (Juz III; Beirut: Dar al-Fikr, t. th.), h. 14. 
Syari'at dihadirkan di bumi melalui Rasulullah bertujuan untuk mewujudkan keadilan hukum, kemaslahatan, dan kebajikan. Oleh karena itu, setiap ketentuan atau aturan hukum yang tidak memenuhi asas keadilan, dipandang bertentangan dengan syari'at Islam (pen. bukan syari'at Islam). ${ }^{9}$ Dengan demikian, dapat dipahami bahwaperubahan hukum menurut mazhab alJauziyah terjadi karena perubahan kemaslahatan.

Kemaslahatan sebagai substansi syari'at mengalami perbedaan seiring dengan perbedaan zaman, tempat, situasi, niat, dan adat. Itu artinya bahwa terjadinya perbedaan zaman, tempat, situasi, niat, dan adat menjadi legitimasi dan alasan bagi terjadinya perubahan hukum. Pandangan al-Jauziyah menunjukkan bahwa syari'at Islam bersifat fleksibel dan adaptif dalam merespon setiap perubahan dan perkembangan. Sejatinya, al-Jauziyah berpendapat bahwa hukum Islam dapat ditafsir dan diterjemahkan sesuai konteks sosial umat.

Eksplorasi lebih jauh tentang faktor-faktor perubah dalam hukum Islam versi mazhab al-Jauziyah, sebagai berikut:

\section{Faktor Zaman}

Ketika Nabi saw. berada di Mekkah, kemungkaran tidak langsung dirubah karena pertimbangan zaman. Akan tetapi, setelah fathu Makkah dan umat Islam meraih kemenangan, maka segala kemungkaran dapat dirubah. ${ }^{10}$ Mencegah kemungkaran dalam hukum Islam adalah kewajiban bagi umat Islam, akan tetapi Mekkah di zaman itu belum memungkinkan dilakukan perubahan karena belum berada dalam situasi aman. Ketika Islam datang, masyarakat Mekkah berada dalam zaman kebodohan (jahiliyah), kemungkaran, dan berbagai kejahatan lainnya merajalela di tengah-tengah masyarakat. Dalam keadaan demikian, hukum Islam tidak dapat dipaksakan untuk diterapkan, tetapi melalui berbagai proses yang cukup panjang. ${ }^{11}$

Kaitannya dengan perubahan hukum, al-Jauziyah menunjukkan pada kasus pelarangan khamar yang dilakukan secara bertahap dengan proses yang panjang. Dalam hal ini, pelarangan terhadap khamar dimulai dengan menyatakan

\footnotetext{
${ }^{9}$ Ibid., h. 2.

${ }^{10}$ Ibid., h. 16.

${ }^{11}$ Ibn Qayyim al-Jauziyah, loc. cit.
} 
bahwa khamar itu merupakan kebiasaan orang-orang kafir (QS. al-Nahl (16): 67). Dilanjutkan dengan menyatakan bahwa khamar itu terdapat manfaat dan mudharat, namun mudharatnya lebih besar dari pada unsur manfaatnya (QS. al-Baqarah (2): 219). Tahap berikutnya, adalah pelarangan mengerjakan shalat dalam keadaan mabuk (QS. al-Nisa (4): 43). Tahap terakhir adalah penegasan bahwa meminum khamar dan perbuatan-perbuatan tercela lainnya harus dijauhi, sebagaimana yang disebutkan dalam QS. al-Maidah (5): 90.

2. Faktor Tempat

Al-Jauziyah menjelaskan bahwa Nabi saw. melarang memotong tangan musuh dalam medan perang. Larangan ini diberlakukan oleh karena peperangan tersebut terjadi di wilayah musuh. ${ }^{12}$ Hal ini berarti bahwa segala ketentuan hukum yang ditetapkan oleh syari'at pada suatu wilayah, tidak dapat dipaksakan pemberlakuannya di wilayah lain. Dengan demikian, perbedaan tempat dapat berimplikasi pada terjadinya perbedaan dan perubahan hukum.

Pengaruh faktor tempat bagi terjadinya perubahan hukum, juga tampak dalam penjelasan al-Jauziyah tentang kewajiban zakat fitrah berdasarkan makanan pokok dari penduduk suatu tempat. Dalam hal ini, zakat fitrah berupa satu gantang kurma atau gandum bagi penduduk kota Madinah, ditetapkan berdasarkan makanan pokok penduduk Madinah. Oleh karena itu, kewajiban mengeluarkan zakat fitrah bagi umat Islam dalam suatu daerah atau negara didasarkan pada makanan pokoknya. ${ }^{13}$ Dengan demikian, mengeluarkan zakat fitrah berupa makanan pokok, harus sesuai dengan makanan yang dikonsumsi oleh masyarakat pada suatu tempat. Hal ini berarti bahwa perbedaan tempat dianggap sebagai klausa syar'i bagi terjadinya perubahan hukum pada jenis makanan pokok yang dizakati.

3. Faktor Situasi

Dalam pandangan al-Jauziyah, situasi atau kondisi merupakan salah satu sebab bagi terjadinya perubahan hukum. Umar bin al-Khattab tidak memberlakukan hukum

\footnotetext{
${ }^{12}$ Ibid., h. 17.

${ }^{13}$ Ibid., h. 9-10.
} 
potong tangan bagi pencuri karena dalam kondisi paceklik. ${ }^{14}$ Menurut Abbas Mahmud Akkad bahwa tindakan Umar yang tidak menjatuhkan hukuman potong tangan bagi pelaku pencurian, tidak berarti mengabaikan nash karena pencuri tersebut melakukannya secara terpaksa untuk mempertahankan kelangsungan hidupnya. ${ }^{15}$ Oleh karena itu, dapat dikatakan bahwa kondisi yang menyebabkan seseorang tidak dapat menghindar dari perbuatan yang dilarang, pada prinsipnya dapat ditoleransi demi mempertahankan atau meraih maslahat yang lebih baik.

Dalam konteks tersebut, kelaparan yang tidak tertahankan dipandang sebagai keadaan yang memaksa seseorang untuk melakukan pencurian. Menurut teori fikih (ushul) bahwa keadaan yang memaksa (darurat) membolehkan sesuatu yang dilarang, seperti makan babi untuk mempertahankan kehidupan. Ini berarti bahwa keadaan darurat yang memaksa seseorang untuk melakukan perbuatan yang dilarang, pada dasarnya dibolehkan oleh syari'at Islam dalam rangka menjaga jiwa yang merupakan salah satu unsur dari maqasid as-syar'i. Keadaan atau situasi yang menjadi klausa bagi terjadinya perubahan hukum, dimaksdukan untuk meraih maslahat yang besar.

4. Faktor Niat

Kaitannya teori perubahan hukum, al-Jauziyah mengangkat kasus yang berkisar pada peristiwa dimana seorang suami mengatakan kepada istrinya "jika aku mengizinkanmu keluar menuju kamar mandi, maka jatuhlah talakmu". Oleh karena sesuatu dan lain hal, isterinya membutuhkan kamar mandi tersebut, maka berkatalah suaminya "keluarlah". ${ }^{16}$ Oleh karena itu, talak jatuh bagi istri karena kata "keluarlah". Kemudian hal ini dinyatakan kepada seorang mufti dan mufti menegaskan bahwa talak telah jatuh kepada istri dengan perkataan "keluarlah" dari suami. $^{17}$

${ }^{14}$ Ibid., h. 22.

${ }^{15}$ Lihat Abbas Mahmud Akkad, At-Tafkir Faridah Islamiyah (Kairo: Nahdhah Masri, t.th.), h. 100.

${ }^{16}$ Ibn Qayyim, op. cit., h. 44.

${ }^{17}$ Ibid. 
Menurut al-Jauziyah dianggap sebagai suatu kebodohan karena kata "keluarlah" bukan dimaksudkan oleh sang suami tersebut sebagai izin. Tindakan mufti yang menceraikan suami dari istrinya tersebut adalah hal yang tidak diizinkan oleh Allah dan Rasul-Nya. Begitu pula tidak diperbolehkan oleh para imam. ${ }^{18}$ Kasus ini merupakan gambaran hukum bahwa ketetapan hukum tidak boleh mengindahkan niat dari pelaku hukum. Hal ini menunjukkan bahwa posisi niat dalam sistem hukum Islam menempati kedudukan penting yang mampu merubah suatu hukum yang telah ditetapkan.

5. Faktor Adat

Bagi al-Jauziyah, adat identik dengan 'urf yang dipandang sebagai faktor perubah hukum. Disebutkan oleh al-Jauziyah bahwa orang yang bersumpah untuk tidak mengendarai "dabbah". Istilah "dabbah" sesuai dengan urf/adat yang berlaku diartikan dengan keledai. Oleh karena itu, sumpahnya hanya berlaku untuk tidak mengendarai hewan yang bernama keledai. Jika seseorang mengendarai kuda atau onta, maka tidak ada konsekuensi hukum baginya. ${ }^{19}$ Begitu pula sebaliknya, jika yang dimaksud "dabbah" sesuai dengan adat/urf pada daerah lainnya adalah kuda, maka sumpahnya tersebut hanya berlaku untuk hewan kendaraan yang bernama kuda. Hal ini menunjukkan bahwa perubahan hukum selalu mempertimbangan adat/urf suatu daerah.

Lebih lanjut al-Jauziyah, jika seseorang mendatangimu dari daerah yang berlainan denganmu dan meminta keputusan hukum, maka tanyakanlah tentang adat/urf yang berlaku di daerahnya dan berilah keputusan hukum berdasarkan adat/urf yang berlaku di daerahnya bukan berdasarkan adat/urf yang berlaku di daerahmu. ${ }^{20}$ Demikian juga halnya seorang mufi tidak dibolehkan mengeluarkan fatwa berdasarkan adat/urf yang terjadi pada zaman yang

${ }^{18}$ Ibid.

${ }^{19}$ Ibid., h. 43.

${ }^{20}$ Ibid., h. 67. Bandingkan dengan Muhammad Said al-'Asymawy, Jauhar al-Islam (Cet. III; Kairo, Sina, 1993), h. 29. 
telah berlalu. $^{21}$ Dari uraian teori perubahan hukum yang terkait dengan adat tersebut, maka seorang penegak hukum hendaklah selalu mempertimbangkan faktor-faktor yang mempengaruhi penetapan suatu hukum. Ini juga berarti bahwa seorang mufti, pembuat dan penegak hukum harus berwawasan luas dan mengetahui aspek-aspek yang berpengaruh dalam penetapan hukum.

Dalam konteks tersebut, perubahan hukum menurut mazhab al-Jauziyah berdasar pada realitas kehidupan masyarakat yang selalu berubah-ubah. Perubahan realitas kehidupan manusia menyebabkan terjadinya perubahan kebutuhan dan maslahat. Implikasi dari perubahan kebutuhan dan maslahat adalah terjadinya perubahan hukum menjadi sesuatu yang tak dapat dihindari. Hal ini berarti bahwa hukum harus selalu ditafsir dan dirubah dalam rangka mewujudkan kemaslahatan umat manusia. Oleh karena itu, setiap diktum hukum yang dipandang tidak memberikan maslahat bagi manusia akibat perubahan, maka harus dikontekskan agar memenuhi kemaslahatan.

Di sisi lain, adanya perubahan hukum tersebut sesungguhnya sejalan dengan misi ajaran Islam yang senantiasa selalu relevan dengan situasi dan kondisi masyarakat, atau dalam istilah lain al-islam shalih lizaman wa makan. Esensi perubahan hukum yang disebutkan, pada dasarnya merupakan bahagian kecil dari sekian banyak permasalahan yang konsensus hukumnya bisa saja berbeda pada zaman, tempat, kondisi yang berlainan. Oleh karena itu, diperlukan suatu usaha yang keras dalam rangka menyelaraskan realitas kehidupan dengan hukum Islam yang bersumber dan berlandaskan al-Qur'an dan al-sunnah.

\section{PENUTUP}

Mengacu pada uraian yang telah dikemukakan di atas, ditarik simpulan bahwa bagi al-Jauziyah hukum Islam tidak stagnan pada suatu tempat, keadaan dan waktu tertentu, akan tetapi senantiasa berkembang mengiringi perubahan yang mengitari manusia. Oleh karena itu, gagasan al-Jauziyah tentang

${ }^{21}$ Nadiyah Syarif al-Umry, Ijtihad fi al-Islam, Ushuluhu, Ahkamuhu, Afatuhu (Cet. I; Beirut: Muassasah al-Risalah, 2001), h. 246. 
perubahan hukum pada dasarnya merupakan upaya kontekstualisasi hukum Islam sesuai dengan realitas kehidupan manusia. Dengan demikian, kemajuan peradaban umat Islam yang ditandai dengan kemajuan sains dan teknologi, mengharuskan dilakukan pengkajian hukum Islam secara kreatif. Dengan pengertian bahwa hukum Islam harus selalu ditafsir dan dikontekskan agar dapat memenuhi rasa keadilan dan kemaslahatan manusia dengan mempertimbangkan faktor al-amkinah (tempat), al-azminah (zaman), al-ahwal (keadaan), al-niat (niat/kemauan), dan al-awaid (adat).

\section{DAFTAR PUSTAKA}

Akkad,Abbas Mahmud.Al-Tafkir Faridah Islamiyah. Kairo: Nahdhah Masri, t.th.

al-'Asymawy, Muhammad Said.Jauhar al-Islam. Cet. III; Kairo, Sina, 1993.

Departemen Agama RI. Al-Qur'an dan Terjemahnya. Jakarta: Proyek Pengadaan Kitab Suci al-Qur'an, 1992.

Ensiklopedi Islam di Indonesia. Jakarta: Direktorat Jenderal Pembinaan kelembagaan Agama Islam Depag RI, 1992.

Haq, Hamka. Syariat Islam; Wacana dan Penerapannya. Makassar: yayasan Ahkam, 2003.

Hasan, Abdillah F. Tokoh-tokoh Mashur Dunia Islam. Cet. I; Surabaya: Jawara, 2004.

al-Hifny, Abdul Mu'im.Mausu'at al-Sufiyah. Cet. I; Kairo: Dar ar-Rasyad, 1992.

al-Jauziyah, Ibnu Qayyim.I'lam al-Muwaqqi'in 'an Rab al'Alamin. Juz III; Beirut: Dar al-Fikr, t. th. 
al-Kahlani, Muhammad Ismail. Subul al-Salam min Adillat alAhkam. Beirut: Dar al-Fikr, 1979.

Salim, Muhammad faraj. Al-Wajiz fi Ushul al-Fiqhi. Cet. II; Kairo: al-Iman, 1965.

al-Umry, Nadiyah Syarif.Ijtihad fi al-Islam, Ushuluhu, Ahkamuhu, Afatuhu. Cet. I; Beirut: Muassasah alRisalah, 2001.

Zaedan, Abdul Karim. Al-Wajiz fi Ushul al-Fiqhi. Cet. II; Beirut: Muassasah al-Risalah, 1987.

Zuhrah, Abu. Ushul al-Fiqh. Mesir: Dar al-Fikr, al-Arabiy, t.th. 